\title{
KONFLIK KELAS DAN FENOMENA KOMUNISME DALAM HUBUNGAN STRUKTURAL MENURUT PANDANGAN KARL MARX
}

\author{
Ahmad Syadzali \\ Jurusan Akidah Filsafat Fakultas Ushuluddin IAIN Antasari Banjarmasin
}

\begin{abstract}
Classconsciousnessis the important key wordin understanding Marx's thought. This phenomenonis actually theantithesisof theHegelianway ofthinkingthat is tooidealistic, which is thenreversedbyMarxin the context ofa moreempirical view. Hence theconcept ofcommunism is evolved by laterMarx's thought interpreters which become the extreme thinking against variousideologies, including religiousideology whichis in favor of thebourgeoisie.
\end{abstract}

Kata-kunci: Karl Marx, kesadaran kelas, borjuisasi.

\section{Pendahuluan}

Pemikiran Marx, harus diakui telah banyak mempengaruhi pemikir-pemikir sosial belakangan, melampaui hal itu pemikiran Marx telah menjelma menjadi sebuah ideologi dan lebih diarahkan pada wilayah praxis. Pada dasarnya Marx memang berupaya untuk menjungkirbalikkan pandangan sebelumnya, yang terkesan mengawang-awang pada tataran ideal, sebagaimana tardapat dalam pemikiran Hegel yang lebih menekankan pada peran "roh". Bagi Marx peran "roh" harus diambil alih oleh manusia, karena manusia adalah sosok yang konkrit dalam mempengaruhi gerak dunia, oleh sebab itu lah filsafat Marx sering disebut sebagdi filsafat praxis, karena pemikirannya lebih menekankan pada action atau tindakan.

Perkembangan selanjutanya menunjukkan bahwa pemikiran Marx banyak diapresiasi, khususnya di Eropa menjelang akhir abad XIX hinggga awal abad XX, dan sekarang pun pemikiran Marx masih tetap diperbincangkan, meskipun kadangkadang dianggap telah usang.

Sebagai sebuah pemikiran, teori-teori Marx merupakan sumber kajian penting dalam sosiologi, di samping Durkheim dan Weber. Sesudah masa Marx banyak muncul para penafsirnya, di antaranya seperti Karl Korsch, Karl Kautsky, Goerg Lukacs, Leszek Kolakowski, dan Adam Schaff. Selain itu mazhab pemikiran yang muncul belakangan pun seperti Frankfurt School mendapatkan inspirasinya dari Marx. 
Bagi para pengkaji ataupun para politisi, pemikiran Marx memiliki sisi menarik, karena secara teoritis ia merupakan objek kajian akademis yang sangat berguna sebagai titik tolak pengembangan hipotesis-hipotesis yang muncul belakangan, dalam rangka merespon berbagai perubahan yang terkait dengan realitas sosial, khususnya dalam konteks kajian filsafat ilmu sosial. Sedangkan dalam konteks politik, pemikiran Marx digunakan sebagai referensi dalam membangun landasan ideologis, meskipun sudah mengalami banyak reduksi di sana-sini.

\section{Latar Belakang Pemikiran Marx}

Karl Marx adalah seorang filsuf Jerman keturunan Yahudi yang dilahirkan di Trier, 5 Mei 1818, meskipun orang tuanya Yahudi, namun ia dibesarkan secara Protestan, karena ayahnya sendiri berpindah ke agama tersebut. Sebagai penganut agama itu Marx dipermandikan secara Protestan. Pada masa-masa kehidupan awal, Marx banyak dipengaruhi oleh lingkungan keluarga dan sekitarnya, termasuk pertumbuhan bakat intelektualnya, oleh sebab itulah kecenderungan terhadap filsafat diperoleh dari ayahnya, sedangkan dalam kesusasteraan dipengaruhi oleh Baron Von Westphalen, yang kelak menjadi mertuanya. ${ }^{1}$

Pada perkembangan berikutnya, Marx sebagai seorang intelektual muda mulai terjun kedunia pemikiran, di Berlin ia mulai bergabung dengan sebuah kelompok yang terdiri dari para intelektual muda yang kritis dan radikal, yaitu "Klub Para Doktor", pada saat itu Marx masih tergolong yunior. Kelompok ini memiliki kecenderungan kuat untuk menggunakan filsafat Hegel sebagai alat untuk mengkritik situasi politik di Prussia pada saat itu, yang mereka anggap terjebak dalam sistem otoriter. Bagi kelompok ini Hegel dianggap sebagai guru revolusi, dan karena pandangan-pandangan yang radikal itu mereka disebut sebagai kelompok Hegelian muda, atau Hegelian sayap kiri, dan sebagai lawannya dihadapkan dengan kelompok Hegelian sayap kanan. ${ }^{2}$ Dari sini jelaslah bahwa Marx mulai bersentuhan dengan pemikiran filsafat Hegel, yang dikemudian hari mempengaruhi jalan pikirannya.

Tahap berikutnya, setelah Marx bertemu dengan pemikiran filsafat Hegel, ia tidak lantas mengambil atau mengikuti pemikiran itu sepenuhnya, tetapi ia justru melakukan kritik tajam terhadap pemikiran Hegel. Salah satu kritik Marx terhadap Hegel adalah tentang pengetahuan absolut yang dianggap sebagai titik akhir perjalanan filsafat melalui segala fenomen pengalaman dan kesadaran. Setelah itu seakan-akan pengetahuan absolut filsafat telah selesai, dan tak ada lagi sesuatu yang baru yang dapat dipikirkan pasca Hegel. Problem berikutnya juga muncul dari persoalan di atas, bahwa pengetahuan absolut tidak mesti sesuai dengan realitas, dunia sendiri dianggap sama sekali tidak filosolis, karena dunia terpecah belah ketika berhadapan dengan sebuah filsafat total, untuk itulah Marx mencoba membumikan filsafat pada tataran praxis. ${ }^{3}$ Di samping Hegel, masih ada tokoh lainnya seperti Feuerbach yang turut mempengaruhi cara pandang Marx, meskipun

\footnotetext{
1 Harry Hamersma, Tokoh-tokohFilsafat Barat Modern, (Jakarta: Gramedia 1992), h. 67.

2 Franz von Magnis, Karl Marx, (Jakarta: Gramedia,1999), h. 47.

3 Franz von Magnis, Karl Marx, h. 55-64.
} 
Feuerbach sendiri tak terlepas dari sengatan kritiknya, salah satu kritik tersebut adalah bahwa Feuerbach masih tidak realistis, materialismenya masih terkurung dalam doktrin filsafat, yang hanya merupakan sekumpulan gagasan hasil dari renungan terhadap realitas material. ${ }^{4}$ Untuk sampai pada tingkat kematangan pemikirannya, Marx selalu mencoba membenturkan ide-ide segarnya dengan teoriteori terdahulu, sebelum menatanya kembali menjadi gagasan-gagasan yang khas dirinya.

\section{Beberapa Pandangan Marx}

\section{Borjuasi dan Alat Produksi}

Memperbincangkan tentang borjuasi sudah barang tentu terkait dengan sejarah kapitalisme itu sendiri. Sejarah kapitalisme bila dilihat dari asal-usulnya merupakan bentuk perkembangan atau penjelmaan dari feodalisme. Sebelum mencapai tahap perkembangan menuju kapitalisme, feodalisme merupakan bentuk yang lebih sederhana, di mana ia meletakkan fundamen perekonomiannya pada pertanian dan sedikit ditopang oleh industri-industri lokal. Pada umumnya feodalisme lebih terpusat di pedesaan, khususnya dalam konteks abad pertengahan. Kemudian jika dilihat dalam hubungan kerjanya antara kaum feodal dan para pekerja, maka unsur alienasinya lebih kecil, meskipun para pekerja itu menyerahkan hasil kerjanya, dalam jumlah tertentu kepada sang majikan. Dengan kata lain hanya ada sedikit alienasi antara produsen dengan produknya, maka dalam hal ini si pekerja masih bisa menikmati hasil kerjanya, baik untuk dirinya ataupun keluarganya. Sedangkan tuan tanah tidak terlalu berupaya mengambil keuntungan yang maksimum sebagaimana halnya dalam kapitalisme. ${ }^{5}$

Perkembangan berikutnya mengindikasikan adanya perubahan atau pergeseran dari feodalisme ke kapitalisme, fenomena ini diawali dengan produksi yang melebihi konsumsi. Kenyataan ini memberikan inspirasi kepada sejumlah individu untuk memproduksi jenis-jenis barang dalam jumlah yang berskala besar, maksudnya tidak lain untuk menggalakkan tingkat penjualan hasil produksinya, sehingga dari hasil penjualan itu bisa ditarik keuntungan yang sebesar-besarnya dalam rangka menambah akumulasi kapital yang ada. Kemudian dari individu-individu yang memiliki kapital besar ini lah muncul kelas borjuasi. ${ }^{6}$ Dengan makin kokohnya kedudukan kelas borjuasi, maka pasar pasar semakin meluas, kebutuhan masyarakat pun semakin meningkat. Seiring dengan dengan makin canggihnya alat-alat produksi yang dikuasai oleh borjuasi modern, maka industri modern dan pasar dunia pun mereka rebut. ${ }^{7}$ Bisa dipastikan pengandaian Marx dan Engels ini benar meskipun dalam konteks

\footnotetext{
${ }^{4}$ Anthony Giddens, Capitalism and Modern Social Theory: an Analysis of Writing of Marx, Durkheim and Max Weber, terj. Soehaba, (Jakarta: UIP, 1986), h. 25.

5 Anthony Giddens, ,Capitalism and Modern..., h. 36-37.

6 Tom Campbell, Seven Theories of Human Society, terj. F.Budi Hardiman, (Yogyakarta: Kanisius, 1994), h. 150.

7 Karl Marx and F. Engels, Manifesto of The Communist Party, terj. KomisiPenterjemah: D.N. Aidit (et.al), (Jakarta: JajasanPembaharuan, 1964), h. 51-52.
} 
kekinian, jika kapital mereka masih tetap kuat, maka kelas borjuasi ini akan terus berjaya, dan dengan mudah mereka mengatur irama pasar sesuai dengan keinginannya, bahkan tidak hanya gerak pasar saja yang bisa dikendalikan, tetapi juga menyangkut kebijakan-kebijakan politis sejauh menyangkut perlindungan bagi kepentingan-kepentingan ekonomisnya, yang menyangkut modal dan penguasaan alat-alat produksi.

Keberadaan kelas borjuasi ini dalam pandangan Marx mengakibatkan adanya gape dengan kelompok masyarakat yang tidak memiliki kapital, sehingga memunculkan differensiasi dalam konteks kelas sosial ekonominya. Mulai dari sinilah terjadi kontak hubungan kerja antara pemilik kapital dengan masyarakat tak berpunya. Masyarakat tak berpunya sebagai pekerja, mau tidak mau harus terlibat dalam kegiatan produksi agar bisa bertahan hidup, hal ini disebabkan dengan terbatasnya sarana produksi, atau alat-alat produksi masih belum tersebar secara merata. ${ }^{8}$ Hubungan kerja antara kelas borjuasi dan para pekerja sudah jelas didominasi oleh kelas yang berkapital besar, dengan demikian para pekerja memiliki tingkat ketergantungan besar terhadap kelas borjuasi.

\section{Masyarakat dan Alienasi}

Perbincangan tentang masyarakat dalam pemikiran Marx tidak terlepas dari adanya kelas dan kerja. Ada pun masyarakat yang dimaksud adalah kelas pekerja yang tertindas. Jika dilihat dari sifat dasarnya, masyarakat atau ummat manusia adalah makhluk yang memiliki kecenderungan alamiah untuk bertindak kreatif, hanya saja dengan keberadaan kapitalisme, sifat kreatif yang dimiliki manusia menjadi terdistorsi, yang dengan demikian manusia telah kehilangan sifat khasnya. ${ }^{9}$

Bila dilihat dari sifat dasarnya manusia mampu menyatakan dirinya, karena lewat dunia ia membangun dirinya dalam sejarah, hasil kerja manusia merupakan kesaksian nyata dari perealisasian diri, yang dengan segenap potensinya manusia mampu mengubah objek alami. Dalam konteks ini alam sebagai objek dari pekerjaan manusia telah menerima bentuk baru dari si pekerja itu sendiri. Dengan kata lain dunia telah diubah lewat pekerjaan yang melibatkan seluruh generasi ummat manusia dari dulu hingga kini, sehingga alam yang kita temui sekarang bukan lagi bersifat alami, tetapi merupakan hasil karya manusia. ${ }^{10}$

Sehubungan dengan gambaran di atas, bahwa pekerjaan dalam sejarah umat manusia pada tahapan selanjutnya telah mengalami kemerosotan, manusia tidak lagi bebas menyatakan diri lewat kreasinya, ia telah dibatasi oleh kepentingan kelas borjuasi, yang semuanya mengendalikan tatanan produksi dengan kekuatan kapitalnya. Mulai dari sinilah pekerjaan bersifat mengalienasi, di mana pekerja dipisahkan dari hasil kerjanya, sehingga mereka (kaum pekerja) tidak bisa memiliki atau menikmati hasil kerjanya. Produk atau hasil kerjanya adalah sesuatu yang

\footnotetext{
${ }^{8}$ Doyle Paul Johnson, Sociological Theory Classical Founders and Contemporary Perspectives, terj. Robert M.Z. Lawang, (Jakarta: Gramedia, 1986), h. 134.

9 Anthony Giddens, ,Capitalism and Modern..., h. 19.

${ }^{10}$ Franz von Magnis, Filsafat Sebagai Ilmu Kritis, (Jakarta: Kanisius, 1992), h. 137-138.
} 
asing bagi si pekerja. Selain itu pekerja-pekerja tidak mempunyai kewenangan untuk menjual produk-produknya, bahkan sebaliknya para pekerja diperlakukan sebagai suatu komoditi yang bisa diperjual-belikan kepada majikan-majikan lain, sebagai akibatnya para pekerja kehilangan sifat otonom terhadap dirinya dalam konteks pekerjaan dan hasil kerjanya. Para pekerja adalah sapi perahan, semakin banyak ia menghasilkan produk semakin sedikit hasil yang diperoleh, semakin banyak nilai surplus yang ia ciptakan semakin tidak berharga si pekerja, dan yang menikmati surplus itu tidak lain adalah para majikan. ${ }^{11}$

Seiring dengan majunya teknologi industri, maka alat-alat produksi pun mengalami perkembangan, para pemilik kapital sudah barang tentu sangat berkepentingan dengan teknologi yang dianggap bisa menunjang kepentingan produksinya, oleh sebab itulah mesin-mesin mulai digunakan, akibatnya peran pekerja mulai dikurangi, dan para pekerja itu sendiri tidak lebih sebagai lampiran tambahan dari mesin-mesin produksi. Inilah sebuah fenomena transisi yang menarik menuju industri modern, di mana para pemilik kapital melebarkan jaringan usahanya lewat pabrik-pabrik besar yang sifatnya lebih terorganisir. ${ }^{12}$

Adapun bentuk pengorganisasian itu lebih terarah pada para pekerja, sebagaimana dijelaskan dalam Manifesto komunis.

"Massa kaum buruh yang dikumpulkan dalam pabrik, diorganisasikan seperti serdadu. Sebagai serdadu biasa dari tentara industri, mereka diatur di bawah perintah suatu susunan kepangkatan yang rapi terdiri dari opsiropsir dan sersan-sersan. Mereka tidak hanya menjadi budak kaum borjuis dan budak negara borjuis saja; mereka itu setiap hari dan setiap jam diperbudak oleh mesin-mesin, oleh mandor-mandor, dan terutama sekali oleh tuan-tuan pabrik borjuis itu sendiri”. ${ }^{13}$

Jika dilihat dalam konteks industri kapitalis, pengandaian Marx itu menggambarkan semakin meningkatnya alienasi terhadap para pekerja, mereka tidak hanya teralienasi dari hasil kerjanya, tetapi juga terasing dari orang per orang, karena mereka masing-masing lebih banyak berhadapan dengan perangkat-perangkat produksi (mesin-mesin). Selain itu jenjang pertuanan semakin bertambah, sehingga perangkat produksi yang paling dasar dikendalikan secara hirarkis menurut aturan si pemilik kapital.

Pandangan Marx tentang alienasi, jika ditarik pada horison yang lebih luas sebenarnya tidak hanya menyangkut kaum pekerja saja, tetapi juga menyangkut kaum pemilik kapital. Kelas borjuasi sebagai penghasil keuntungan atau pencipta kapital, secara sadar atau tidak, telah dialienasi oleh sejumlah kapital yang mereka miliki, termasuk juga alat-alat produksi yang merupakan aset penting. Dengan ungkapan lain kesadaran kelas borjuasi telah dikuasai oleh nilai-nilai material yang terkandung dalam kapital, sehingga pandangan dunianya dikonstruksikan berdasarkan nilai-nilai tersebut. Namun bagaimanapun kelas borjuasi tetap lah

11 Anthony Giddens, ,Capitalism and Modern..., h. 14-15.

${ }^{12}$ Karl Marx and F. Engels, Manifesto..., h. 59.

${ }^{13}$ Karl Marx and F. Engels, Manifesto..., h. 59-60 
penikmat hasil kerja dari bawahannya, karena mereka yang mengaproppriasi surplus produksi.

Sisi yang lain menunjukkan, bahwa keseluruhan hubungan dalam kapitalisme menciptakan lingkaran ketergantungan dari kelas-kelas yang saling berkepentingan, dan tingkat ketergantungan yang lebih tinggi tetap berada pada kelas pekerja rendahan. Dalam beberapa kasus lokal (bukan dalam konteks Barat), kadang-kadang ditemukan kenyataan bahwa pekerja "rela" dibayar di bawah standar upah minimum, hal ini disebabkan karena alasan adanya kesulitan mencari lapangan pekerjaan lain.

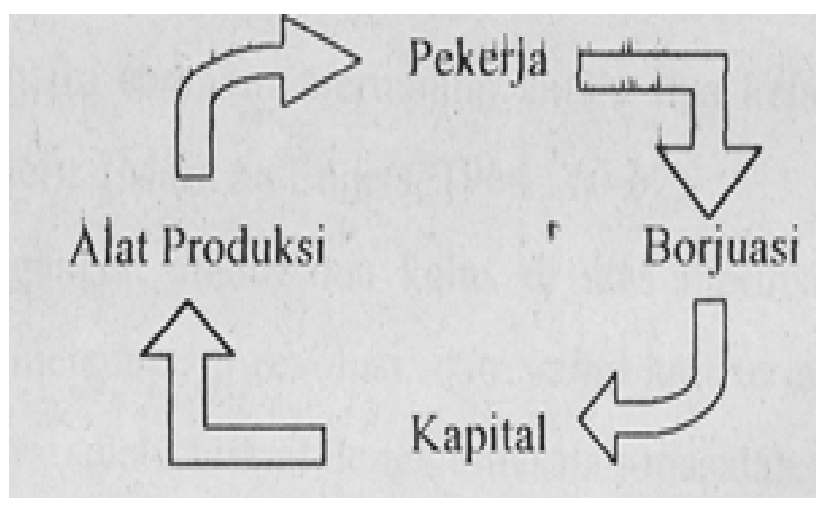

Pada intinya seluruh pertarungan di medan kompetisi dalam kapitalisme modern tetap dimenangkan oleh kelas borjuasi, selama tidak ada reaksi dari kelas pekerja yang mengarah kepada konflik untuk menghancurkan dominasi para kapitalis.

\section{Kesadaran kelas dan konflik}

Sebagai kelas tertindas para pekerja menyadari perlu adanya perbaikan nasib, dengan adanya kesamaan prinsip untuk bebas dari penghisapan kelas borjuasi, menyebabkan munculnya kesadaran kelas secara kolektif. Namun kemunculan kesadaran kelas pekerja (proletar) tidak begitu saja, menurut Marx kesadaran itu muncul dengan ditandai adanya perjuangan untuk melawan borjuasi dari orang per orang, kemudian setelah itu muncul prakarsa untuk melakukan konsolidasi terhadap seluruh pekerja, dan setelah semuanya memiliki kemantapan sikap, dimulailah perlawanan terhadap borjuasi. Bentuk perlawanan ini diekspresikan dengan kekuatan fisik yaitu tindakan berupa pengrusakan terhadap alat-alat produksi serta barang-barang import. Pada taraf ini menurut Marx, para pekerja merupakan massa lepas yang tersebar di seluruh negeri, dan dari massa mengambang ini kekuatan terpecah karena adanya rivalitas di antara mereka sendiri. Tahap berikutnya adalah munculnya kesadaran untuk bersatu dari kelas pekerja, seiring dengan bertambahnya massa yang terkonsentrasi menjadi kekuatan besar. Bibit konflik pun mulai ditaburkan dengan adanya hura-hara, yang kemudian pertentangan itu semakin meruncing antara dua kelas yang saling berseteru. ${ }^{14}$

${ }^{14}$ Karl Marx and F. Engels, Manifesto..., h. 60-62. 
Ketegangan antara dua kelas di atas merupakan saat-saat yang rawan bagi meledaknya revolusi, dan setiap kali terjadi ledakan revolusi menurut Marx selalu terkait dengan masalah-masalah sosial yang menjadi latar belakangnya, yaitu adanya halangan dari institusi-institusi lama, yang tidak memberikan jalan bagi pemenuhan kehendak yang menyangkut kebutuhan atau hajat hidup. Selain itu ditambah dengan adanya represi yang memperburuk keadaan. ${ }^{15}$

Fenomena menguatnya gerakan perlawanan kaum pekerja (proletar) mengakibatkan terpecahnya kaum borjuasi, sehingga ada di antara kelas ini yang bergabung dengan massa proletar yang revolusioner, kecenderungan untuk bergabung dengan kelas yang revolusioner tentulah memiliki maksud untuk penyelamatan, agar terhindar dari berbagai benturan dengan arus massa yang semakin menguat. Pada akhirnya menurut pengandaian Marx, keruntuhan borjuasi dan kemenangan kaum proletar adalah sesuatu yang tidak terhindarkan. ${ }^{16}$

Masa berikutnya adalah saat peralihan, di mana masyarakatnya tidak memiliki hak-hak perorangan, yang diakui hanyalah hak milik bersama, dan perekonomian pun didasarkan pada aturan ekonomi bersama. ${ }^{17}$ Perubahan di atas dilandasi oleh adanya keyakinan, bahwa dengan penghapusan kelas kapitalis akan tercipta model ekonomi baru tanpa penindasan. ${ }^{18}$ Meskipun demikian, untuk mencapai tujuan yang diinginkan, yaitu menuju masyarakat komunis, haruslah melalui fase di mana berkuasanya diktator proletariat, penguasa baru inilah yang mengatur batas-batas kepemilikan, serta mendistribusikan hasil-hasil produksi kepada masyarakat. Kemudian setelah tercapainya pemerataan, maka barulah masyarakat komunis memasuki fase terakhir, yaitu saat-saat menikmati kemakmuran, di mana tidak ada lagi differensiasi antara buruh kasar dan halus, sehingga kerja pun di dasarkan pada kesanggupan dan keperluan masing-masing orang. ${ }^{9}$

Apa yang diandaikan oleh Marx di atas tentang kemungkinan akan terjadinya konflik yang mengarah pada revolusi, ternyata tidak terjadi di Eropa Barat atau negara-negara industri maju. Kritik ini sebagaimana yang dikemukakan oleh Doyle P. Johnson, Magnis ataupun Dahrendorf. Namun walaupun demikian gagasan revolusi Marx ini telah mengilhami revolusi Bolshevik di Rusia, pada tahun 1917 yang dipimpin oleh Lenin (Vladimir Ulyanov), kemudian revolusi Cina yang dipimpin Mao Tse Tung.

Secara keseluruhan, model konflik yang mengarah pada revolusi dalam pandangan Marx, bisa digambarkan sebagai berikut:

15 Karl Marx,Revolution and Counter Revolution, terj.FathulMu'in (et.al), (Yogyakarta:Jendela, 2000), h. 2

${ }^{16}$ Karl Marx and F. Engels, Manifesto..., h. 62-67.

17 Herbert Giersch, AllgemeineWirtschaftspolitik, terj. Samik Iberahim dan Nadirsjah Tamin, (Jakarta:Kedutaan Besar Jerman,1968), h. 171.

${ }_{18}$ Raymond Aron, Essai Sur Libertes, terj. Rahayu S. Hidayatet.al.,(Jakarta: YOI, 1993), h. 22.

${ }_{19}$ Herbert Giersch, Allgemeine..., h. 171-172. 


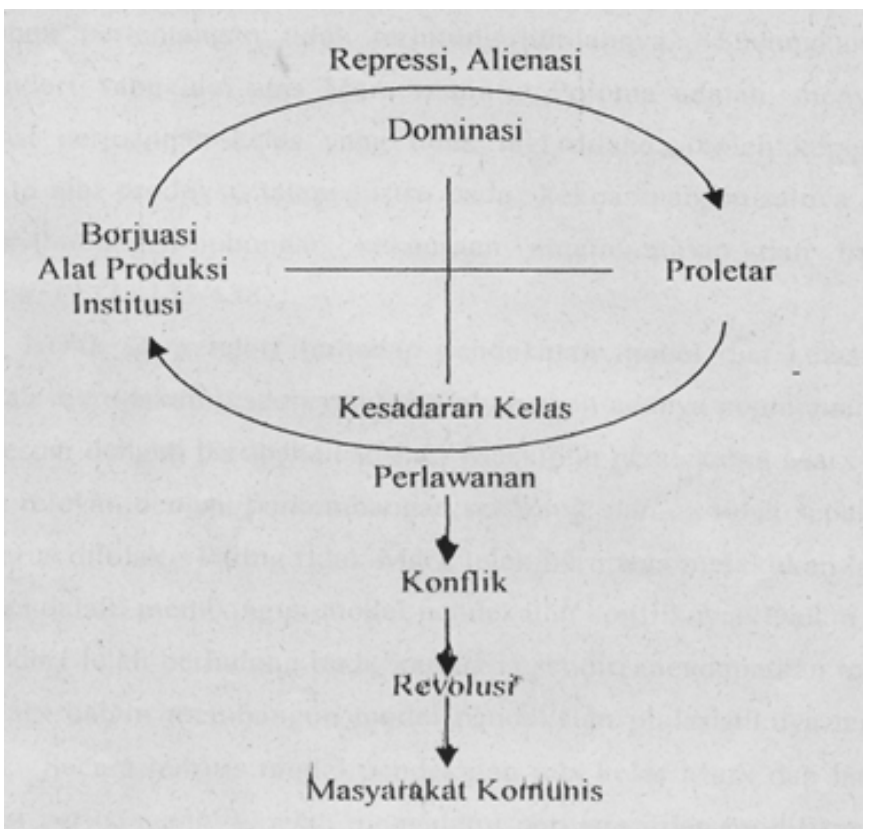

Model konflik yang diketengahkan Marx lebih bersifat dua kelas yang sederhana, yaitu dengan menggunakan seluruh masyarakat sebagai unit analisa, yang dalam hal ini dibagi menjadi dua, pertama, kelompok yang menguasai alat produksi, sedangkan yang kedua, kelompok yang tergantung pada pemilik alat produksi. Sehubungan dengan model Marx, menurut Poloma, Dahrendorf mengkritik pendekatan dua kelas ini, yang dalam pandangannya pendekatan model Marx tidak bisa diterapkan secara keseluruhan, tetapi hanya pada kelompok-kelompok tertentu saja. Sebagai alternatif, menurut Poloma, Dahrendorf mengajukan model pluralistik dalam melihat konflik. Dalam model plularistik ini ditemukan bahwa medan pertentangan tidak hanya dalam pengertian dikotomis, tetapi saling tumpang tindih, di mana kelompok-kelompok pertentangan tidak terhitung jumlahnya. Sedangkan kritik Dahrendorf yang lain atas Marx menurut Poloma adalah, menyangkut motivasi perjuangan kelas yang tidak lagi dilandasi oleh kepentingan terhadap alat produksi, tetapi justru pada kekuasaaan, misalnya dengan adanya hubungan-hubungan kekuasaan antara atasan dan bawahan. ${ }^{20}$

Kritik Dahrendorf terhadap pendekatan model dua kelas Marx, tentu lah merupakan respon yang mengharuskan adanya peninjauan ulang yang sesuai dengan perubahan sosial. Meskipun pendekatan Marx di atas kurang relavan dengan perkembangan sekarang, namun tidak sepenuhnya pula harus ditolak. Paling tidak Marx telah berupaya melakukan langkah hipotetis dalam membangun model pendekatan konfliknya. Dalam hal ini Dahrendorf telah berhutang budi, karena ia sendiri mendapatkan inspirasi dari Marx dalam membangun model pendekatan plularistiknya terhadap konflik. Secara teoritis model pendekatan dua kelas Marx dan landasan motivasi perjuangannya, telah mengalami perluasan dan modifikasi yang lebih canggih dari Dahrendorf. 


\section{Analisis}

Pandangan-pandangan Marx yang telah diuraikan sebelumnya, tidaklah merupakan sebuah gagasan yang secara tiba-tiba muncul kepermukaan. Rumusanrumusan gagasan Marx secara epistemologis tentulah beranjak dari titik tolak tertentu, yang dalam hal ini Marx memfokuskannya pada realitas sosial yang kompleks dalam konteks zamannya. Dua hal penting sehubungan dengan realitas sosial yang dikaji oleh Marx yaitu, aspek politis dan ekonomis, karena dua hal tersebut merupakan salah satu tema besar zamannya, yang juga merupakan kelanjutan perdebatan wacana pada zaman-zaman sebelumnya.

Secara historis, pandangan Marx yang berkaitan dengan realitas sosialnya, diilhami oleh situasi kondisi negara Jerman yang pada saat itu menunjukkan adanya penajaman perbedaan kelas, yaitu antara kelas bangsawan dan tani. Dalam percaturan politik dan ekonomi, kelas bangsawan lah yang lebih mendominasi, sehingga kebijakan politis lebih banyak didasarkan pada kepentingan-kepentingan supremasi kelas bangsawan (menengah). Selain sebab di atas, Marx juga semakin terobsesi untuk menyusun pandangannya, sebagai respon terhadap pandangan Hegel yang melegitimasi peran kelas menengah (bangsawan) dalam kancah politik pada saat itu. ${ }^{21}$

Refleksi Marx terhadap realitas sosial zamannya telah melahirkan suatu gagasan yang berpihak pada kelas tertindas, untuk itu ia mencoba membawa gagasannya pada wilayah praxis, sebagai upaya pembalikan dari tradisi berpikir idealisme Jerman.

Keinginan Marx untuk mengaplikasikan gagasannya pada wilayah praxis dilandasi oleh keyakinan akan adanya proses transformasi sosial, bagi Marx yang penting adalah bagaimana gagasan-gagasan bisa bekerja pada wilayah kesadaran manusia, yang secara praktis bisa mengubah nasibnya melalui gerakan-gerakan kolektif yang progresif.

Penekanan Marx pada gagasan-gagasan yang berorientasi praxis merupakan kritik terhadap para filsuf idealis, yang hanya "menggantung" gagasan-gagasan pada langit kamar kerjanya. Oleh sebab itulah dalam Theses of Feuerbach, Marx melontarkan kritiknya, "the philosophers have only interpreted the world, in various ways; the point, however, is to change it". ${ }^{22}$

Menurut Dahrendorf, apa yang telah dirintis oleh Marx (sehubungan hal di atas), adalah salah satu jalan keluar untuk mengatasi kesenjangan antarateori dan praxis, yang dalam hal ini teori diposisikan berdampingan dengan realitas dunia manusia, karena teori-teori itu sendiri berakar dari realitas manusia, baik yang ada di masa lalu maupun masa kini. Teori-teori itu sendiri bukanlah sebagai sesuatu yang final serta sempurna, tetapi merupakan bagian dari suatu proses yang belum selesai. Menurut Dahrendorf, dalam memahami teori-teori sosialnya, Marx tidak

${ }^{20}$ Margaret M.Poloma, Contemporary Sociological Theory, terj.TimPenterjemahYasogama, (Jakarta: RajawaliPers, 1987), h.135-138.

${ }^{21}$ Karl Marx,Revolution..., h. 6-22.

${ }^{22}$ KarlMarx, "Theses On Feuerbach" dalamOn Religion, (Moscow: Fereign Languages Publishing House,1955), h. 72. 
memposisikan hal itu sebagai sesuatu yang stagnan, tetapi hanya sebagai rumusanrumusan yang bersifat hipotetis. ${ }^{23}$

Kadang-kadang pemikiran Marx dijadikan sebagai sebuah ideologi, sehingga kehilangan sisi kristisnya, kenyataan ini tentulah bertentangan dengan keinginan Marx, karena ia sendiri menggunakan rumusan-rumusan pemikiran hipotetisnya sebagai kritik ideologi. Sebagai contoh, Marx tidak hanyut dalam arus pemikiran zamannya, sehingga ia mampu melakukan kritik terhadap beberapa teori ataupun tokoh. Beberapa sasaran kritik Marx adalah, terhadap idealisme Hegel, penolakan terhadap Materialisme Feuerbach, kritik terhadap kelompok sosialis-humanis, dan kritik yang terkait dengan persoalan ekonomi dan politik pada zamannya. ${ }^{24}$

Dari apa yang dikritik ataupun ditolaknya, Marx mencoba merekonstruksinya menjadi sebuah pandangan yang terintegrasi dari berbagai unsur pemikiran, misalnya ia ingin mencoba mengintegrasikan unsur-unsur yang ada di antara idealisme dan rasionalisme, dengan terus berupaya melengkapi berbagai kekurangannya. ${ }^{25}$ Sikap kritis Marx terhadap aliran-aliran pemikiran, tentulah dilandasi oleh kesadaran untuk melampaui apa yang telah menjadi prestasi parafilsuf yang sebelumnya. Melalui pertautan teori dan praxis-lah ia menemukan pemahaman tentang dunia dan manusia, sebagaimana yang kita jumpai dalam berbagai karya.

\section{Simpulan}

Buah pernikiran Marx adalah hasil kecerdasan membaca dan menafsirkan fenomena zamannya, meskipun pemikiran Marx mengundang pro dan kontra, namun harus diakui pemikirannya telah banyak mempengaruhi pemikir-pemikir sesudahnya, ataupun dalam konteks politik telah dipraktekkan meskipun lebih bersifat ideologis.

Bagi sebagian orang, pemikiran Marx mungkin dianggap telah usang, atau bagi para pemujanya, buku Das Kapital dianggap sebagai kitab suci. Terlepas dari persoalan tersebut di atas, secara umum teori apapun, meskipun telah tua, tetaplah memiliki nilai guna untuk menganalisis kasus tertentu, atau juga sebagai titik tolak bagi rumusan-rumusan hipotesis baru. Sebuah teori yang usang bisa berguna apabila ia telah dimodifikasi menurut konteks zamannya, hal ini sebagaimana yang telah dilakukan oleh Dahrendorf.

Teori-teori sosial yang telah dirumuskan Marx, harus diakui telah memberikan kontribusi yang sangat berarti bagi perkembangan sosiologi, meskipun ia hanya salah satu di antara sekian banyak tokoh yang mempengaruhi gerak pemikiran zaman sesudahnya.

23 Ralf Dahrendorf, "PenceminanTeori Sosial dan Praktek Politik" dalam Christopher Lloyd (Ed.), Social Theory and Political Practice, terj. Nazaruddin Sjamsuddin et.al.,(Jakarta: RajawaliPers, 1986), h. 49.

${ }^{24}$ Terry Johnson, et.al.,The Structure Social Theory, (London: Mac Millan, 1984), h. 121.

${ }^{25}$ Jorge Larrain, The Concept of Ideology, terj. Ryadi Gunawan, (Yogyakarta: LKPSM-NU, 1996), h. 31. 


\section{Daftar Pustaka}

Aron, Raymond, (1993). Essai Sur Libertes, terj. Rahayu S. Hidayat et.al., Jakarta: YOI.

Campbell, Tom, (1994). Seven Theories of Human Society, terj. F.Budi Hardiman, Yogyakarta: Kanisius.

Dahrendorf, Ralf, (1986). "PenceminanTeoriSosialdanPraktekPolitik" dalam Christopher Lloyd (Ed.), Social Theory and Political Practice, terj. Nazaruddin Sjamsuddin et.al., Jakarta: Rajawali Pers.

Giddens, Anthony, (1986). Capitalism and Modern Social Theory: an Analysis of Writing of Marx, Durkheim and Max Weber, terj. Soehaba, Jakarta UIP.

Giersch, Herbert, (1968). Allgemeine Wirtschaftspolitik, terj. Samik Iberahim dan Nadirsjah Tamin, Jakarta: Kedutaan Besar Jerman.

Hamersma, Harry, (1992). Tokoh-tokobFilsafat Barat Modern, Jakarta: Gramedia.

Johnson, Doyle Paul, (1986). Sociological Theory Classical Founders and Contemporary Perspectives, terj. Robert M.Z. Lawang, Jakarta: Gramedia.

Johnson, Terry et.al., (1984). The Structure Social Theory, London: Mac Millan, Larrain, Jorge, (1996). The Concept of Ideology, terj. RyadiGunawan, Yogyakarta: LKPSMNU.

Magnis, Franz von, (1992). Filsafat Sebagai Ilmu Kritis, Jakarta: Kanisius.

—, (1999). Karl Marx, Jakarta: Gramedia,.

Marx, Karl, (1955). "Theses On Feuerbach" dalam OnRelegion, Moscow: Fereign Languages Publishing House.

-_, (2000). Revolution and Counter Revolution, terj. Fathul Mu'in (et.al), Yogyakarta:Jendela.

Marx, Karl and F. Engels, (1964). Manifesto of The Communist Party, terj. Komisi Penterjemah: D.N. Aidit (et.al), Jakarta: Jajasan Pembaharuan.

Poloma, Margaret. M., (1987). Contemporary Sociological Theory, terj. Tim Penterjemah Yasogama, Jakarta: Rajawali Pers. 